\title{
Nurse competence in implementing public health care
}

\author{
Suprapto, Trimaya Cahya Mulat, Nur Syamsi Norma Lalla
}

Department of Nursing, Polytechnic Sandi Karsa Makassar, Indonesia

\begin{tabular}{l} 
Article Info \\
\hline Article history: \\
Received Oct 21, 2020 \\
Revised Jan 28, 2021 \\
Accepted Mar 8, 2021 \\
\hline Keywords: \\
Nurse competence \\
Public health care \\
Community health center \\
Training
\end{tabular}

\begin{abstract}
Health development is a way of increasing awareness, willingness and ability to live healthy for everyone so that an optimal degree of public health can be achieved. The purpose of knowing how the relationship between nurse competence and community health care activities. This study employed quantitative approach and correlation analysis. The population was nurses who work at public health center in Makassar City, Indonesia, however there were 118 nurses who meet the criteria in their selection. There were relationships between attitudes, skills, and competencies with the level of implementation of community health services and that there is an interaction between competence and training. The results of the competency analysis obtained an OR value of 6.429 , meaning that public health center nurses who have good competence have a chance of 6.429 times to carry out community health care activities optimally. Most dominant with the implementation of public health care is the interaction between competence and training. The competence of nurses need to be improved in order to optimize the implementation of community health services through training, coaching through assigned teams, and collaborating with peers and providing support in the form of policies for rewards and sanctions such as nurse career paths.
\end{abstract}

This is an open access article under the CC BY-SA license.

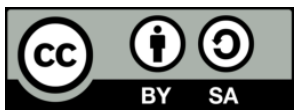

Corresponding Author:

Suprapto

Department of Nursing

Polytechnic Sandi Karsa Makassar

Green Bulurokeng Residency Blok/D 11 Makassar, Indonesia

Email: atoenurse@gmail.com

\section{INTRODUCTION}

Nursing management is a process of nursing services through nurses to provide nursing care, treatment, and a sense of security to patients, families and communities [1]. The implementation of the community service program in Sleman Regency based on [2] illustrates that only $33.01 \%$ of public health center nurses in Sleman Regency carry out the community health program according to their existing job descriptions. Research [3] in Agam District shows that knowledge and motivation are related to compliance with health care services but not with compliance with the administration of health care services. Skills, availability of facilities and infrastructure, as well as perceptions of community health management are related to the compliance of health care services and also compliance with the administration of health care services [4]. Stated that one of the dominant factors related to the performance of public health center nurses in conducting community health services was the ability of officers. That to see someone's performance can be seen from behavior [5]. The ability of nurses is needed in supporting the goals to be achieved from the implementation of community health services. This ability is shown from the competence possessed by nurses in providing health services to the community. Research on the competence of public health center nurses, especially in community service activities, is deemed necessary. 
Competencies needed to analyze health problems that exist in the community to conduct an evaluation. The expected competencies include skills in analyzing public health assessments, skills in planning public health programs, communication skills, skills in understanding community culture, skills for working with communities and stakeholders, skills in using public health science, skills for financial management, and leadership skills and systematic thinking [6]. Ability to use infrastructure (technology and language), ability to interact with various heterogeneous groups, and ability to act in accordance with their authority in carrying out health efforts [7]. Bureaucratic discretion in regional government as an effort to the effectiveness of public services is issued in an urgent situation, namely a situation that appears suddenly concerning the public interest which must be resolved quickly, where in order to solve the problem, the laws and regulations have not regulated it [8]. This shows that nurses who have good job satisfaction will have the desire to provide more energy and responsibility in supporting the success and welfare of the hospital [9]. Primary health services (Puskesmas) burdens service providers to make optimal use of limited resources in order to achieve maximum health benefits for the population served [10].

The ability of nurses is needed in supporting the goals to be achieved from the implementation of public health care. This ability is shown from the competence possessed by nurses in providing health services to the community. Reports for public health care activities, especially home visits, are still not optimal. Other activities include visits to planned priority groups such as integrated care centers for the elderly or toddlers who are more impressed with routine services with more services towards treatment or immunization, whereas community health care activities can be used as opportunities for public health center nurses to develop their abilities. The ability referred to is such as conducting counseling or as early detection in overcoming existing health problems so that they do not become a bigger problem. This research on the competence of public health center nurses, especially in community health care activities, is felt to be done. This aims to find out how these competencies relate to community health care activities, besides that, because research on the competence of public health center nurses has never been carried out in Makassar city.

\section{RESEARCH METHOD}

This study employed a quantitative descriptive research design. Research variables are competence, knowledge, attitudes, and skills of nurses in providing public health services. The population in this study were all nurses who worked as many as 118 nurses. The sample in this study was the entire population, namely all nurses who met the inclusion criteria to be the sample in this study purposive sampling. The questionnaire consists of questions with a single choice with variables of competence, knowledge, attitudes, skills and level of implementation of public health nurse activities. The questionnaire is made in the form of a Google Form and has been tested for validity.

Research has obtained ethical approval with letter number: 089/LP2M/PT/SK/IV/2020. On the Google form, there is research information that explains the objectives, benefits, guarantees of data confidentiality for respondents and researcher contacts, the respondent's consent sheet, respondents can choose the option to agree or not, contains a statement questionnaire according to the variables This research was conducted in April-June 2020. Method of data collection was carried out using data collection instruments in the form of measuring instruments made specifically by the researchers themselves based on existing literature, with stages, editing, coding and data tabulation. Univariate, bivariate data analysis used the Chi-Square statistical test with the help of SPSS 21. The study was conducted after obtaining a recommendation letter and research permit from the institution where the research was conducted and paying attention to informed concent, anonymity and confidentiality. The research principles used in this research are the principle of benefit, the principle of respecting human rights and the principle of justice.

\section{RESULTS AND DISCUSSION}

The data that has been collected is processed through four stages, namely editing, coding, processing, and cleaning. Furthermore, the data were analyzed using a computer statistical program in sequence; univariate analysis, bivariate analysis with Chi-square and independent $\mathrm{t}$ test, and multi-variate analysis with multiple logistic regression.

Table 1 shows that results of the analysis show that each sub variable has a p-value $<0.05$ except for knowledge, meaning that the null hypothesis on attitudes, skills, and competencies failed to be rejected while the null hypothesis on knowledge was rejected. The conclusion that can be drawn is that there is no relationship between knowledge and the level of implementation of community health services. On the other hand, there is a relationship between attitudes, skills and competencies with the level of implementation of community health services. The results of the analysis on competence obtained an OR value of 6.429, meaning that health center nurses who have good competence have a chance of 6.429 times to carry out community health activities optimally 
Table 1. Analysis of the relationship between the competence of nurses and the level of implementation of community health activities

\begin{tabular}{ccccccccc}
\hline & \multicolumn{3}{c}{$\begin{array}{c}\text { Implementation of community services } \\
\text { Variable }\end{array}$} & $\begin{array}{c}\text { Optimal } \\
\%\end{array}$ & $\mathrm{n}$ & $\begin{array}{c}\text { Not optimal } \\
\%\end{array}$ & $\mathrm{n}$ & \multicolumn{2}{c}{ OR (95\%) CI } & p-value \\
\hline Knowledge & & & & & & & & \\
Well & 29 & 43.3 & 38 & 56.7 & 67 & 100 & 0.929 & 0.992 \\
Less & 23 & 45.1 & 28 & 54.9 & 51 & 100 & $(0.45-1.93)$ \\
Attitude & & & & & & & & \\
Well & 35 & 66 & 18 & 34 & 53 & 100 & 5.49 & 0.000 \\
Less & 17 & 26.2 & 48 & 73.8 & 65 & 100 & $(2.48-12.14)$ \\
Skills & & & & & & & & \\
Well & 39 & 65 & 21 & 35 & 60 & 100 & 6.429 & 0.000 \\
Less & 13 & 22.4 & 45 & 77.6 & 58 & 100 & $(2.85-14.51)$ \\
Competence & & & & & & & & \\
$\quad$ Well & 40 & 66.7 & 20 & 33.3 & 60 & 100 & 6.429 & 0.000 \\
Less & 12 & 20.7 & 46 & 79.3 & 58 & 100 & $(2.85-14.51)$ \\
\hline Source: Pim
\end{tabular}

Source: Primary data, 2020

Table 2 shows that results of the multivariate analysis show that nurses who have good competence and have attended training will run community health services 16,661 times compared to nurses who have good competence and have attended training. The results above indicate that there is an interaction between competence and training so that the two variables influence each other.

Table. 2 Analysis of multivariate analysis of competence and implementation level of public health care

\begin{tabular}{|c|c|c|c|c|c|}
\hline Variable & B & p-value & $\operatorname{Exp}(\mathrm{B})$ & Lower & Upper \\
\hline Competence & -1.679 & 0.329 & 0.184 & 0.006 & 5.437 \\
\hline Training & -1.815 & 0.269 & 0.163 & 0.007 & 4.072 \\
\hline Training_competence & 2.813 & 0.026 & 16.661 & 1.401 & 198.167 \\
\hline Constant & -0.655 & 0.795 & 0.520 & & \\
\hline
\end{tabular}

That education, work environment conditions with the quality of nursing services, there is a relationship between workload and quality of nursing services [11]. Notoatmodjo [12] to that the measurement of knowledge can be done by interviewing a questionnaire that asks about the content of the material to be measured from the research subject. That the use of homecare services is considered effective, if there are the following aspects; reliability, responsiveness, assurance, empathy and direct evidence provided by officers [13]. That the attitude of nurses is related to the frequency of conducting health education and comfort in providing interesting topics because attitude is one of the factors that influence the formation of behavior [14]. Development of nurses' abilities in implementing community services and policy support [15]. Incorporation of these competencies into healthcare system expectations, orientations, job descriptions, performance appraisals, and clinical ladder promotion processes could drive higher quality, reliability, and consistency of healthcare as well as reduce costs [16].

Due to the current limited understanding of the full impact of various existing climate change adaptation strategies, it focuses on the unintended positive and negative consequences of public health adaptation [17]. Nurses with better communication competency had more professional competence [18]. That nurses have not demonstrated the competence necessary to offer holistic health care to people with genetic conditions. Pre- and post-registration programs should be scaled up to include genetic health care [19]. To maintain and improve the competence and cooperation of nurse educators, interventions are needed [20]. Community nurses had important role in promotive and preventive care in community [21]. That waiting time, the cause of disease, and cleanliness of the waiting room are important predictors of patient satisfaction [22]. That image has a positive effect on patient loyalty. However, found that satisfaction, perceived value, and perceived sacrifice had no significant effect on patient loyalty. Management of health care institutions must pay attention to and manage the image of the institution in a proactive manner [23].

Prepare a nursing workforce with competencies to prioritize oral disease prevention and health promotion, provide evidence-based oral health care in a variety of practice settings, and collaborate on an interprofessional basis. teams across the health care system [24]. The expansion of the Family Health Strategy requires managerial competencies of implementing and sustaining change, negotiating agreements and commitments, using power and influence ethically and effectively, sponsoring and selling new ideas, and 
encouraging and promoting innovation [25]. Organizational, work process, patient-related, individual, social and professional factors contribute to the proliferation of workarounds. Group norms, local and Organization culture, 'being competent', and collegiality influence the implementation of workarounds [26]. The nurses who were confident were more likely to have had actual prior experience in disasters or shelters. Selfregulation of behavior (motivation) was a significant predictor of perceived nurse competence to manage disasters only in regard to the nurse's willingness to assume the risk of involvement in a disaster situation [27]. Assessment of nurse competency category level using the nurse competency scale which shows a good level of competence [28]. Increasing public awareness of their rights to obtain services, including health services, is a positive indicator of increasing awareness of the importance of health [29]. Improve the task of community nurses through modification of nurse commitment, interpersonal influence factors, personal factors and situational influence factors. The patient outcomes of a health organization depend on the knowledge, skills and motivation of its individual employees. Therefore, it is important for health care employers to motivate their workers in order to meet the desired outcomes [30].

\section{CONCLUSION}

That there is a relationship between attitudes, skills and knowledge in the implementation of community service activities. The most dominant factor with the implementation of community health services is the interaction between competence and training. Developing the competence of nurses through training, coaching through assigned teams, or collaborating with colleagues and disseminating nurses' competencies in running community health services regularly through regular meetings and supervision carried out by the team given the task. This study recommends increasing the competence of nurses in order to optimize the implementation of community health services through training, coaching through assigned teams, or collaborating with colleagues and providing support in the form of policies for rewards and sanctions such as a nurse's career path.

\section{REFERENCES}

[1] D. A. Gillies, "Nursing management as a systems approach," Bandung: Yayasan IAPKP., 2000.

[2] M. Daruji, "The Relationship between Individual Factors of Perkesmas Coordinator Officers with Implementation of Tasks in Program Management at Public Health Centers in Sleman Regency in 2001," Thesis, Diponegoro University, 2001.

[3] Nurmalis, "Evaluation of the implementation of community health care by village midwives in Agam District," Thesis, Universitas Gajah Mada, Yogyakarta, 2007.

[4] M. Septino and T. Hasanbasri, "Evaluation of the implementation process of public health care at the District Health Center of Lima Puluh Kota District," Thesis, Masters Program in Policy and Management of Health Services, Gadjah Mada University, 2007.

[5] J. Gibson, J. Ivancevich, and R. Konopaske, "Organizations: Behavior, structure, processes," McGraw-Hill Higher Education, 2011.

[6] Y. Tafwidhah, E. Nurachmah, and R. T. S. Hariyati, "Competencies of Puskesmas Nurses and Level of Implementation of Community Health Care Activities," Jurnal Keperawatan Indonesia, vol. 15, no. 1, pp. 21-28, 2012.

[7] O. DeSeCo, "The definition and selection of key competencies," Executive summary, OCDE-USAID. Recuper. En, http//www. deseco. admin. ch/bfs/deseco/en/index/02. html. 2005.

[8] Suprapto Suprapto, "Implementation of Discretionary Policies in Health Services Health Insurance Administering Bodies (Bpjs)," Journal of Health Sciences Sandi Husada, vol. 7, no. 1, pp. 1-8, 2019.

[9] Suprapto Suprapto, "Relationship between satisfaction with nurse work performance in health services in hospitals," Indian Journal of Public Health Research \& Development, vol. 10, no. 10, pp. 785-788, 2019, doi: 10.5958/0976-5506.2019.02912.7.

[10] R. O. Boadu, P. Agyei-Baffour, and A. K. Edusei, "Data accuracy and completeness of monthly midwifery returns indicators of Ejisu Juaben Health Directorate of Ghana," International Journal Public Health Science, vol. 8, no. 1, pp. 106-117, 2019.

[11] S. Suprapto, "Nursing Work Stress Factors Related to the Quality of Nursing Services in the Emergency Room in the Salewangan Regional Hospital, Maros Regency," Journal of Health Sciences Sandi Husada, vol. 4, no. 1, pp. 1-10, 2016.

[12] S. Notoatmodjo, "Public health,” Jakarta: Rineka Cipta, vol. 413, 2011.

[13] Suprapto Suprapto, "The Effectiveness of Using Homecare Services in Health Services at Barombong Health Center, Makassar City," Journal of Health Sciences Sandi Husada, vol. 7, no. 2, pp. 201-204, 2018.

[14] L. W. Green, M. Kreuter, S. G. Deeds, and K. B. Partridge, "Health education planning: A diagnostic approach," in Health Education Planning: A Diagnostic Approach, p. 306, 2018.

[15] S. Nanda, "The Relationship between Individual Competence and Nurse Performance in the Implementation of Public Health Care in Pariaman City," Jurnal Kesehatan, vol. 11, no. 2, 2020. 
[16] B. M. Melnyk, L. Gallagher-Ford, L. E. Long, and E. Fineout-Overholt, "The Establishment of Evidence-Based Practice Competencies for Practicing Registered Nurses and Advanced Practice Nurses in Real-World Clinical Settings: Proficiencies to Improve Healthcare Quality, Reliability, Patient Outcomes, and Costs," Worldviews Evidence-Based Nursing, vol. 11, no. 1, pp. 5-15, 2014, doi: 10.1111/wvn.12021.

[17] J. J. Cheng and P. Berry, "Health co-benefits and risks of public health adaptation strategies to climate change: a review of current literature," International Journal Public Health, vol. 58, no. 2, pp. 305-311, 2013, doi: 10.1007/s00038-012-0422-5.

[18] Y.-H. Ahn, E.-K. Kweon, E.-S. Choi, and E.-J. Gu, "Effects of competency level in communication on professional competence of public health nurses," Journal Korean Public Health Nursing, vol. 25, no. 2, pp. 233-243, 2011.

[19] H. Skirton, A. O'Connor, and A. Humphreys, "Nurses' competence in genetics: a mixed method systematic review," Journal of Advanced Nursing, vol. 68, no. 11, pp. 2387-2398, 2012, doi: 10.1111/j.13652648.2012.06034.x.

[20] L. Salminen, S. Minna, K. Sanna, K. Jouko, and L.-K. Helena, "The competence and the cooperation of nurse educators," Nurse Education Today, vol. 33, no. 11, pp. 1376-1381, 2013, doi: https://doi.org/10.1016/j.nedt.2012.09.008.

[21] S. Sismulyanto, N. Nursalam, and F. Efendi., "Model to predict duty of community nurses in promotive and preventive care," International Journal Public Health Science, vol. 8, no. 1, p. 26, 2019, doi: 10.11591/ijphs.v8i1.13461.

[22] D. Mesfin and T. Gintamo, "Patient satisfaction and associated factors with services provided at outpatient departments," International Journal Public Health Science, vol. 8, no. 4, pp 406, 2019, doi: 10.11591/ijphs.v8i4.20375.

[23] M. Yarmen, "The Effect of Satisfaction, Perceived Value, Image, and Perceived Sacrifice on Public Healthcare Service Institution's Patient Loyalty," International Journal Public Health Science, vol. 6, no. 3, p. 275, 2017, doi: 10.11591/ijphs.v6i3.7634.

[24] M. C. Dolce, J. Haber, and D. Shelley, "Oral Health Nursing Education and Practice Program," Nursing Research and Practice, vol. 2012, no. Special Issue, pp. 1-5, 2012, doi: 10.1155/2012/149673.

[25] I. M. V. Lowen, A. M. Peres, K. Crozeta, E. Bernardino, and C. L. C. Beck, "Managerial nursing competencies in the expansion of the Family Health Strategy," Revista da Escola de Enfermagem da USP , vol. 49, no. 6, pp. 964-970, 2015.

[26] D. S. Debono et al., "Nurses' workarounds in acute healthcare settings: a scoping review," BMC Health Services Research, vol. 13, no. 1, pp. 175, 2013, doi: 10.1186/1472-6963-13-175.

[27] S. Baack and D. Alfred, "Nurses' Preparedness and Perceived Competence in Managing Disasters," Journal of Nursing Scholarship, vol. 45, no. 3, pp. 281-287, 2013, doi: 10.1111/jnu.12029.

[28] O. Numminen, R. Meretoja, H. Isoaho, and H. Leino-Kilpi, "Professional competence of practising nurses," Journal of Clinical Nursing, vol. 22, no. 9-10, pp. 1411-1423, 2013, doi: 10.1111/j.1365-2702.2012.04334.x.

[29] A. Pananrangi.M, A. Nippi, R. Panyyiwi, and S. Suprapto, "Quality of Health Services at Public Health Center Padongko," Journal of Health Sciences Sandi Husada, vol. 12, no. 2, pp. 748-752, 2020, doi: 10.35816/jiskh.v12i2.398.

[30] W. K. Aruasa, L. K. Chirchir, and S. K. Chebon, "Implications of physicians and nurses' professional satisfaction on patient care," International Journal Public Health Science, vol. 8, no. 3, p. 300, 2019, doi: 10.11591/ijphs.v8i3.20238. 